\title{
方向性ケイ素鋼板で積層された変圧器鉄心の 近似三次元磁界解析
}

$\begin{array}{lllll}\text { 正 } & \text { 中 } \text { 員 } & \text { 高義 } & \text { (岡山大) } \\ \text { 正員 河 瀬 順 洋 } & \text { (岐卓大) }\end{array}$

\section{1. まえがき}

数値解析法の進歩により, 変圧器鉄心内の磁束の振 舞は，かなり明らかになってきだ(1)〜(3)。ところか， 方向性ケイ菜鐝板を使用した三相変圧器鉄心の $T$ 接 合部などでは，ケイ秦鋼板の死延方向が首でとに異な るため, 磁束分布は積廉方向によって異なり，三次元 的である。従って，従来の二次元解析では，磁束分布 および鉄損推定に大きな誤差を伴う。しかしながら, 三次元非線形解析は，計算時間か膨大となるので，乙 のような問題をまともに三次元解析するのは賢明でな W。

そとで著者らは，二次元場の有限要素法を㹡張し て，二次元平面内だけでなく，厚さ方向にもエネル ギー最小の原理を適用し，圧延方向の異なる各々のケ イ素鎡板中の磁束分布を求める，新しい近仪三次元解 析法を開発した(4)(5)。

本論文では，始めに二次元平面内だけでなく，厚さ 方向にもエネルギー最小の原理 ${ }^{(6)}$ を啇用する有限要素 法の定式化の詳細を示す。次に，圧延方向が暴なる二 枚のケイ素鋼放を積層した場合の磁束分布を解析なら びに実験的に求め，本解析法の妥当性を示す。更に， 本手法を三相三脚变圧器鉄心の $T$ 接合部に適用し, 詳細な磁柬分布を求めると共に, 徒来法による解析と 比較検討し，本手法の有用性について示す。

\section{2. 近似三次元磁界解析法}

\section{〈2.1〉基本的な考え方 因 1 は，方向性ケイ素}

Approximation Analysis of Three-Dimensional Magnetic Fields in Iron Cores Laminated with Grain-Oriented Silicon Steel. By Takayoshi Nakata, Member (Dpartment of Electrical Engineering, Okayama University) \& Yoshihiro Kawase, Member (Department of Electrical Engineering, Gifu University).

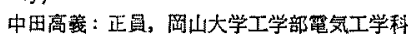

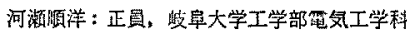

鋼板を皘層した三相内鉄形変圧器鉄心の下半分を示 す。図中の矢印は圧延方向を示し，実線は最上層の鎆 板の王延方向を，また破線はその次の層のそれを示 す。困からわかるように，中央脚下方の $T$ 接合部で は，1故目のケイ素鋼板の圧延方向之 2 放目のそれか 直角に交差している。よって，1枚目と 2 枚目の磁束 分布は，この部分で大きく買なる。従来の二次元場の 有限要素法は， $x-y$ 平面内のみにエネルギ一最小の原 理を適用しているため，z軸方向の磁束分布を求める ことはできない。しかし，图1のような場合には，z 方向の磁束分布を知る必要はなく，各々の層 $(x-y$ 平 面）内の磁束分布が二次元的にわかれば十分であるか ら，完全な三次元解析をする必要はない。

そこで四 2 のうに，压延方向の異なる二尿中の磁 束配分比 $\Phi_{x 1} / \Phi_{x}, \Phi_{x 2} / \Phi_{x}$ を，エネルギー最小の原理 を用いて決定する方法を考案した。図2 は，四1の断 面 $A-A^{\prime}$ の一部で, 矢用で示す磁束 $\Phi_{x}$ の通過方向 の磁気抵抗が異なっている2枚の鋼板 (1), (2)の断面を

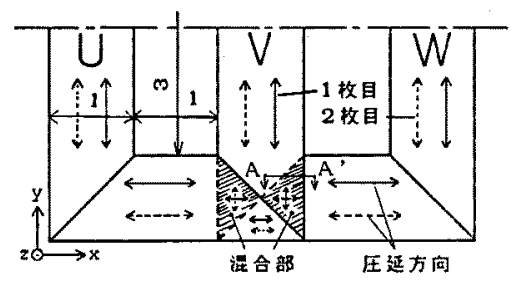

図 1 三相変王器鉄心

Fig. 1. Three-phase transformer core.

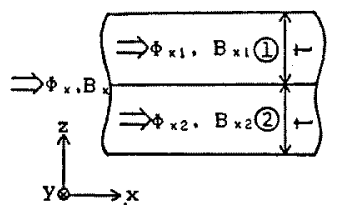

図 2 圧延方向の異なる鈰板の皘層

Fig. 2. Fluxes in each layer. 
示す。総磁束 $\Phi$ \&は, 図に示すように厚さ $t$ の鈯板 (1), (2) K $\Phi_{x 1}, \Phi_{x 2}$ 之なって分流する。

〈2.2〉各々の鋼板への磁束配分比と鋼板中の磁束 密度困2ては，穊単のため $\Phi_{x}, \Phi_{x l}, \Phi_{x 2}$ は、い ずれも $y$ 方向長さ $1 \mathrm{~m}$ あたりの磁束量と定竓する。 また、〈2.3〉節のようにして求められる，それぞれの 板八の磁束の配分比 $F_{x \hbar ， F_{x 2}}$ を次式のように定義す る。

$$
\begin{aligned}
& F_{x 1}=\Phi_{x 1} / \Phi_{x} \\
& F_{x 2}=\Phi_{x 2} / \phi_{x}
\end{aligned}
$$

だし。

$$
F_{x 1}+F_{x 2}=1
$$

よって，それぞれの鎡板の磁束密度 $B_{ \pm 1}, B_{ \pm 2}$ は次式 で表される。

$$
\begin{aligned}
& B_{x 1}=\Phi_{x 1} / t=F_{x 1} \cdot \Phi_{x} / t \quad \ldots \ldots \ldots \ldots \ldots \ldots \\
& B_{x 2}=\Phi_{x 2} / t=F_{x 2} \cdot \Phi_{x} / t=\left(1-F_{x 1}\right) \Phi_{x} / t
\end{aligned}
$$

$x$ 万向の平均的な磁束密 $B_{x}$ はバクトルポテンシャ ル $A$ を用いれば次式で表される(6)。

$$
B_{x}=\hat{\partial} A / \partial y
$$

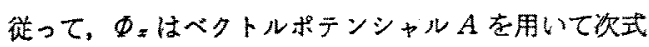
で交される。

$$
\Phi_{x}=2 t \cdot \partial A / \partial y
$$

(7)式を(4)，(5)式代代入し，各釾板中の磁束密度 $B_{x 1}, B_{* 2}$ をへクトルポテンシャルA およひ磁柬配分 比 $F_{x 1}$ を用いて表せ涹次式が得られる。

$$
\begin{aligned}
& B_{x 1}=2 F_{x 1} * \partial A / \partial y \ldots \ldots \\
& B_{x 2}=2\left(1-F_{z 1}\right) \cdot \partial A / \partial y
\end{aligned}
$$

同棦に，y方向の磁束を $\Phi_{y}$ ，それそれれの錔板中の 磁束密度を $B_{y 1}, B_{y 2}$ ，配分比を $F_{y 1}, F_{y^{2}}$ 上すると次式 加得られる。

$$
\begin{aligned}
& B_{y_{1}}=-2 F_{y_{1} \cdot} \cdot \partial A / \partial x \ldots \ldots \\
& B_{y^{2}}=-2\left(1-F_{y_{1}}\right) \cdot \partial A / \partial x
\end{aligned}
$$

り上のようにすれば，1枚ごとの銈板の磁束密度をべ クトルポテンシャルA まよび磁束配分比 $F_{x 1}, F_{y 1}$ を 用いて表すと气が可能である。

〈2.3〉エネルギー樶小の原理を用いた磁束配分比 の決定 ベクトルポデシャルA まよび磁束配分 比 $F_{x 1}, F_{y 1}$ を決定するために，エネルギ一鼠小の原 理を利用する。1枚目および 2 枚目の鎐板のエネル ギー $\chi_{1}, \chi_{2}$ は炊式で与えられるい。

$$
\begin{aligned}
\chi_{1}= & t \iint_{S}\left(\int_{0}^{E_{x 1}} \nu_{x 1} B_{x 1} d B_{x 1}\right. \\
& \left.+\int_{0}^{B_{y 1}} \nu_{y 1} B_{y 1} d B_{y 1}\right) d x d y
\end{aligned}
$$

$$
\begin{aligned}
\chi_{2}= & t \iint_{S} \int_{0}^{B_{x x}} \nu_{x 2} B_{x 2} d B_{x 2} \\
& \left.+\int_{0}^{B_{y z}} \nu_{y^{2}} B_{y^{2}} d B_{y 2}\right) d x d y
\end{aligned}
$$

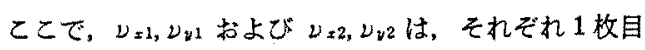
およひ2 枚目の $x$,y方向の磁気抵抗率であり，Sは 解析頜域を示す。よって，総エネルギー $\chi$ は次式に なる。

$$
\chi=\chi_{1}+\chi_{2}
$$

(14)式加最小になる上らに, バクトルポテンシャル

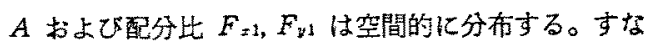
わち,

$$
\begin{aligned}
& \partial \chi / \partial A_{1}=0 \ldots \ldots \ldots \ldots \ldots \ldots \\
& \partial \chi / \partial F_{x 1}=0, \quad \partial \chi / \partial F_{y I}=0 .
\end{aligned}
$$

(14)式は(8)〜 (13)式より明らかなように，Aおよひ $F_{x 1}, F_{y 1}$ の関数で，磁気抵抗率が非線形性を有する。

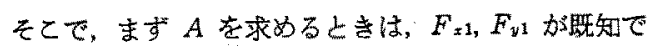
あるとして解き， $F_{x 1}, F_{y 1}$ 点求めるときには $A$ が既 知であるとして，磁気抵抗率を修正しながら解く。こ のように両者を交互に反復させて，最終的な $A, F_{x 1}$, $F_{y 1}$ を求める。

まず，F未、F $F_{y 1}$ を既知しして（15)式より $A$ を求 める。すなわち、ニニートン・ラプソン法を適用すれ ば $n+1$ 回目の反復で得られる節点 $i$ のポテンシャル ○近似解 $A_{i}^{(n+1)}$ (次式で与えられる ${ }^{(6)}$ 。

$$
A_{i}{ }^{(n+1)}=A_{i}{ }^{(n)}+\delta A_{i}{ }^{(n)} \text {. }
$$

ここで, $\delta A_{i}{ }^{(n)}$ は次式を解くことにより求められる(6)。

$$
\left[\frac{\partial^{2} \chi}{\partial A_{i} \partial A_{j}}\right]\left\{\delta A_{i}\right\}=\left\{-\frac{\partial \chi}{\partial A_{i}}\right\} \text {. }
$$

次に，A を既知しして，(16)式上り $F_{x 1}, F_{y 1}$ を求 める。ニニートン法を通用すれば， $k+1$ 回目の反復 で得られる近似解 $F_{x 1}^{(k+1)}, F_{y 1}(k+1)$ は疢式となる。

$$
\begin{aligned}
& F_{x 1}{ }^{(k+1)}=F_{x 1}{ }^{(k)}-\frac{\partial \chi}{\partial F_{x 1}} \mid \frac{\partial^{2} \chi}{\partial F_{x 1}^{2}} \\
& F_{y 1}{ }^{(k+1)}=F_{y 1}{ }^{(k)}-\frac{\partial \chi}{\partial F_{y 1}} \mid \frac{\partial^{2} \chi}{\partial F_{y 1}^{2}}
\end{aligned}
$$

(17) 〜 (19)式の棓算を磁舆抵抗率を修正しなからら反復 し, $A, F_{x 1,} F_{y 1}$ のすべてが収束すれは， $A, F_{* 1}, F_{v 1} の$ 非線形解加得られる。

〈2.4〉定式化 まず始めに（18)式の定式化を 行う。(14)式は(12)，(13)式上り次式になる。

$$
\chi=\chi_{x 1}+\chi_{x 2}+\chi_{y^{1}}+\chi_{y^{2}}
$$

ただし

$$
\chi_{x 1}=t \iint_{S}\left(\int_{0}^{B_{x 1}} v_{x 1} B_{x 1} d B_{x 1}\right) d x d y
$$




$$
\begin{aligned}
& \left.\chi_{x 2}=t \iint_{S}\left(\int_{0}^{B_{x 2}} \nu_{x 2} B_{x 2} d B_{x 2}\right) d x d y\right) \\
& \chi_{y 1}=t \iint_{S}\left(\int_{0}^{B_{y 1}} \nu_{y 1} B_{y 1} d B_{y 1}\right) d x d y \\
& \left.\chi_{y 2}=t \iint_{S}\left(\int_{0}^{B_{y 2}} \nu_{y 2} B_{y 2} d B_{y / 2}\right) d x d y\right)
\end{aligned}
$$

(21)式よりわかるように(20)式の右包の四つの項は， いずれもはとんど同じ形なので，右辺第 1 項の $\chi_{x 1}$ に ついて考える。 $\chi_{x 1}$ が $A$ の関数であるとし, $\partial \chi_{x 1} / \partial A_{i}$ を計算すると次式になる。

$$
\begin{aligned}
\frac{\partial \chi_{x 1}}{\partial A_{i}} & =\frac{\partial \chi_{x 1}}{\partial B_{x 1}} \frac{\partial B_{x 1}}{\partial A_{i}} \\
& =t \iint_{S} \frac{\partial B_{x 1}}{\partial A_{i}} \nu_{x 1} B_{x 1} d x d y
\end{aligned}
$$

ここで， $B_{x 1}$ は (8)式および一次三角形要素の補間関 数 ${ }^{\left({ }^{6}\right)} N_{k}$ を用いれぱ次式で表される。

$$
B_{x 1}=2 F_{x 1} \sum_{k=1}^{3} \frac{\partial N_{k}}{\partial y} A_{k} .
$$

$F_{x 1}$ が $A$ の関数でないしして，(23)式を(22)式に代 入すると次式が得られる。

$$
\begin{aligned}
\frac{\partial \chi_{x 1}}{\partial A_{i}}= & 4 t F_{x 1}{ }^{2} \iint_{S} \nu_{x 1} \frac{\partial N_{i}}{\partial y} \sum_{k=1}^{3} \frac{\partial N_{k}}{\partial y} \\
& \times A_{k} d x d y \ldots \ldots \ldots \ldots \ldots \ldots
\end{aligned}
$$

同様に (20) 式の全部の項について計算すると，(18) 式の $\partial \chi / \partial A_{i}$ は次式になる。

$$
\begin{aligned}
\frac{\partial \chi}{\partial A_{i}}= & t \iint_{S k=1} \sum^{3}\left\{4\left(F_{x 1}^{2} \nu_{x 1}+F_{x 1}^{2} \nu_{x 2}\right)\right. \\
& \times \frac{\partial N_{i}}{\partial y} \frac{\partial N_{k}}{\partial y}+4\left(F_{y 1}^{2} \nu_{y i}+F_{\left.y 2^{2} \nu_{y 2}\right)}\right. \\
& \left.\times \frac{\partial N_{i}}{\partial x} \frac{\partial N_{k}}{\partial x}\right\} A_{k} d x d y=0 \ldots . .(25)
\end{aligned}
$$

(18)式の $\partial^{2} \chi / \partial A_{i} \partial A_{j}$ は, $\nu$ が $B$ の関数であるこ とを考虑すると(25)式より次式となる。

$$
\begin{aligned}
& \frac{\partial^{2} \chi}{\partial A_{i} \partial A_{j}}=t \iint_{S}\left\{4\left(F_{x 1}^{2} \nu_{x 1}+F_{x 2^{2}} \nu_{x 2}\right)\right. \\
& \times \frac{\partial N_{i}}{\partial y} \frac{\partial N_{j}}{\partial y}+4\left(F_{y 1}^{2} \nu_{y 1}\right. \\
& \left.+F_{y^{2}}{ }^{2} \nu_{y^{2}}\right) \frac{\partial N_{i}}{\partial x} \frac{\partial N_{j}}{\partial x} \\
& +32\left(F_{x 1} \frac{\partial \nu_{x 1}}{\partial B_{x 1}{ }^{2}}+F_{x 2} \frac{\partial \nu_{x 2}}{\partial B_{x 2}}\right) \\
& \times \frac{\partial N_{i}}{\partial y} \frac{\partial N_{j}}{\partial y} \sum_{k=1}^{3} \frac{\partial N_{k}}{\partial y} A_{k} \sum_{l=1}^{3} \frac{\partial N_{l}}{\partial y} A_{l} \\
& +32\left(F_{y 1} \frac{\partial \nu_{y 1}}{\partial B_{y 1}{ }^{2}}+F_{y 2^{4}} \frac{\partial \nu_{y 2}}{\partial B_{y 2^{2}}}\right)
\end{aligned}
$$

$$
\begin{aligned}
& \left.\times \frac{\partial N_{i}}{\partial x} \frac{\partial N_{j}}{\partial x} \sum_{k=1}^{3} \frac{\partial N_{k}}{\partial x} A_{k} \sum_{l=1}^{3} \frac{\partial N_{l}}{\partial x} A_{l}\right\} \\
& \times d x d y \ldots \ldots \ldots \ldots \ldots \ldots \ldots(26)
\end{aligned}
$$

次に，(19)式の定式化を行う。前述したように， $\chi$ は $A, F_{x 1}, F_{y 1}$ の関数であるが，(25)式を求めたのと 同様に，A の関数ではいとして， $\partial \chi / \partial F_{x 1}, \partial \chi / \partial F_{y 1}$ を 計算すると $(20)$ ，(21)式より次式吕得られる。

$$
\begin{aligned}
& \frac{\partial \chi}{\partial F_{x 1}}=t \iint_{S}\left\{\nu_{x 1} F_{x 1}\left(2 \frac{\partial A}{\partial y}\right)^{2}\right. \\
& \left.-\nu_{x 2}\left(1-F_{x 1}\right)\left(2 \frac{\partial A}{\partial y}\right)^{2}\right\} d x d y \\
& =0 \\
& \frac{\partial \chi}{\partial F_{y 1}}=t \iint_{S}\left\{\nu_{y_{1}} F_{y_{1}}\left(-2 \frac{\partial A}{\partial x}\right)^{2}\right. \\
& \left.-\nu_{y_{2}}\left(1-F_{y 1}\right)\left(-2 \frac{\partial A}{\partial x}\right)^{2}\right\} d x d y \\
& =0
\end{aligned}
$$

$A$ が既知であるとし, עが $B$ の関数であることを考 虑すると, $\partial \chi^{2} / \partial F_{x 1}{ }^{2}, \partial \chi^{2} / \partial F_{y 1}{ }^{2}$ は(27), (28)式上り次 式となる。

$$
\begin{aligned}
\frac{\partial^{2} \chi}{\partial F_{x 1^{2}}}= & t \iint_{S}\left(2 \frac{\partial A}{\partial y}\right)^{2}\left[\nu_{x 1}+\nu_{x 2}+2\left(2 \frac{\partial A}{\partial y}\right)^{2}\right. \\
& \left.\times\left\{F_{x 1}{ }^{2} \frac{\partial \nu_{x 1}}{\partial B_{x 1}{ }^{2}}+\left(1-F_{x 1}\right)^{2} \frac{\partial \nu_{x 2}}{\partial B_{x 2}{ }^{2}}\right\}\right] \\
& \times d x d y \ldots \ldots \ldots \ldots \ldots \ldots \ldots \ldots \ldots \ldots \ldots \ldots \ldots \\
\frac{\partial^{2} \chi}{\partial F_{y 1}{ }^{2}}= & t \iint_{S}\left(-2 \frac{\partial A}{\partial x}\right)^{2}\left[\nu_{y 1}+\nu_{y 2}\right. \\
& +2\left(-2 \frac{\partial A}{\partial x}\right)^{2}\left\{F_{y 1}{ }^{2} \frac{\partial \nu_{y 1}}{\partial B_{y 1}{ }^{2}}\right. \\
& \left.\left.+\left(1-F_{y 1}\right)^{2} \frac{\partial \nu_{x 2}}{\partial B_{y 2}{ }^{2}}\right\}\right] d x d y \ldots(30)
\end{aligned}
$$

(19)式に(27)〜 (30) 式を代入して反復計算を行い, 収束すれば磁束配分比 $F_{x 1}, F_{y 1}$ が得られる。F $F_{x 1}, F_{y 1}$ が求まれば，(25)，(26)式に代入して再度ニュートン・ ラプソン法で $A$ を求める。これを繰返すととにより $A, F_{x 1}, F_{y 1}$ のすべてが収束すれば， $A, F_{x 1}, F_{y 1}$ の非 線形解が得られる。

本手法てはポテンシャル $A$ と磁束配分比 $F_{s 1}, F_{y 1}$ を末知数として収束させるために，ポテンシャル $A$ だけを末知数とする従来法より反復回数は增加する。 しかし，後述の第 3 章の例では，反復回数は最大でも 11 回であり，従来法より1〜3回程度多いだりであっ た。

\section{3. 解析例と検討}

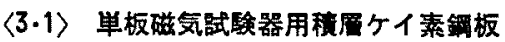
这 3 


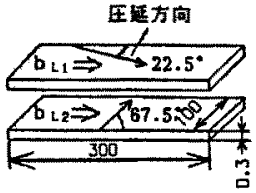

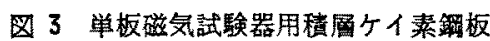

Fig. 3. Laminations of two sheets with different rolling directions.

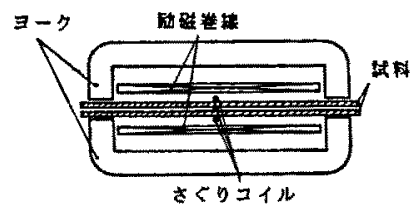

図 4 ダブルョーク形単板磁気試験器

Fig. 4. Double-yoke type single sheet tester.

に示すような単板磁気試験器用のケイ素銅板を，2枚 皘屬したモデルについて解析的ならびに実験的に检討 する。上下の鋼板の圧延方向は，中心線に対し互いに 反対で，1枚目は $22.5^{\circ} ， 2$ 枚目は $-67.5^{\circ}$ の切出し 角になっている。鋼板は $0.3 \mathrm{~mm}$ 厚の高配向性ケイ 素鋼板 $\mathrm{G} 8 \mathrm{H}$ で，周波数は $50 \mathrm{~Hz}$ とする。

実験に结，四4亿示すような上下にヨークがあるダ ブルヨーク形単板磁気試験用测定枠を用いた。このよ うにすれば，試料を 2 枚重ねて測定してむ，各鋼板を 通る磁束に対応した磁路の磁気抵抗は，いずれあ同じ になる。2枚の鋼板はセロハンテープで密着させた。 また，1枚目扰よび2枚目の鋼板中を通る磁束を，そ れぞれの銅板断面積で除した長手方向の磁束密度 $b L 1$, $b_{L 2}$ (図 3 参照) の剆定には，アルミはくで作成した探 りコイルを，図4に示すように曆間化入することに よって行なった。なお，との場合の探りコイル厚さは 約 $20 \mu \mathrm{m}$ である。

四 5 ，図 6 k，低磁束密度之高磁束密度の場合の 1 枚目扰上び2枚目の長手方向の磁東密度 $b_{L L}, b_{L 2}$ の波 形を示す。(a)因は計算波形，(b)因は実䮦波形であ る。図中破線は 2 枚の鋼板中を通る全磁束を龬板総断 面積て除した平均磁束密度波形で， $B_{m}$ はその時間的 な最大值である。図からわかるように， $B_{m}=1.0 \mathrm{~T}$ で は 1 枚目の切出し角 $22.5^{\circ}$ の銅板のほうが磁束の配分 が多い。しかし， $B_{m}=1.4 \mathrm{~T}$ では，1枚目の鎆板が飽 和するため，2枚目の鋼板す磁束がかなり通るように なるととがわかる。図より，本手法の妥当性がわか る。なお多少差があるのは，計算では $x, y$ 方向の碳 束成分のみしか考慮していなく，鎆板に垂直な方向の 成分が無視されているためであろう。

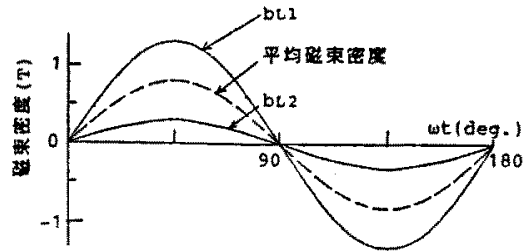

(a) 影算波形

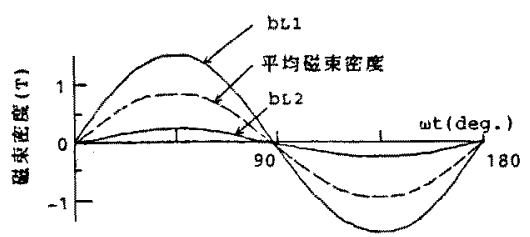

(b) 绕辁波形

図 5 磁束密度波形 $\left(B_{m}=1.0 \mathrm{~T}\right)$

Fig. 5. Waveforms of longitudinal fux density $\left(B_{m}=1.0 \mathrm{~T}\right)$.

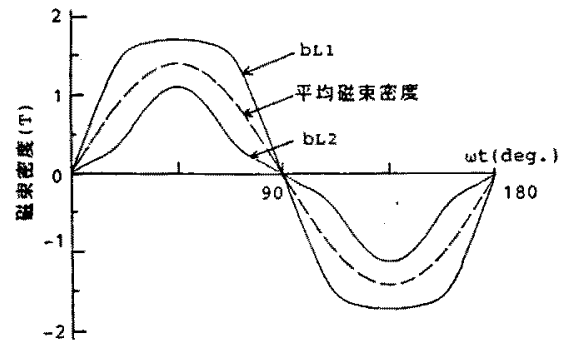

(a) 此策波形

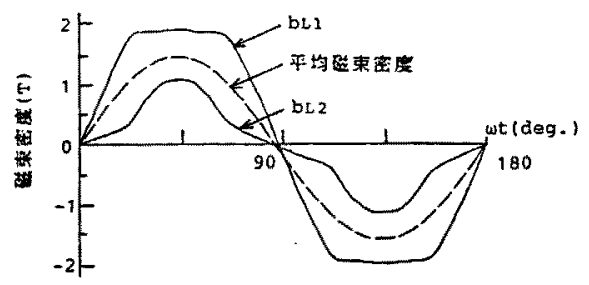

(b) 突飡波形

図 6 磁束密度波形 $\left(B_{m}=1.4 \mathrm{~T}\right)$

Fig. 6. Waveforms of longitudinal flux density $\left(B_{m}=1.4 \mathrm{~T}\right)$.

\section{〈3.2〉 三相内铁形变王器鉄心 $T$ 接合部の解析}

ここでは, 図 1 亿示す三相内鉄形三脚変王器鉄心の 脚の空間的平均磁束密度の時間的な゙最大值 $B_{m}$ が 1.7 Tの場合について, ミク口な磁束および鉄損分布を榆 討すると共に従来法と比較する。なお，材質は方向性 ケイ素鎆板 G 10 とした。

(1) 磁束分布 因 7 K $T$ 接合部におりる1枚 目および2 枚目の磁束密度ベクトルの，因８亿1枚目 と 2 枚目を合世た平均的な磁束分布の時間的変化を示 す。ただし，中央脚の総磁束が最大になる眼間を $\omega t$ 

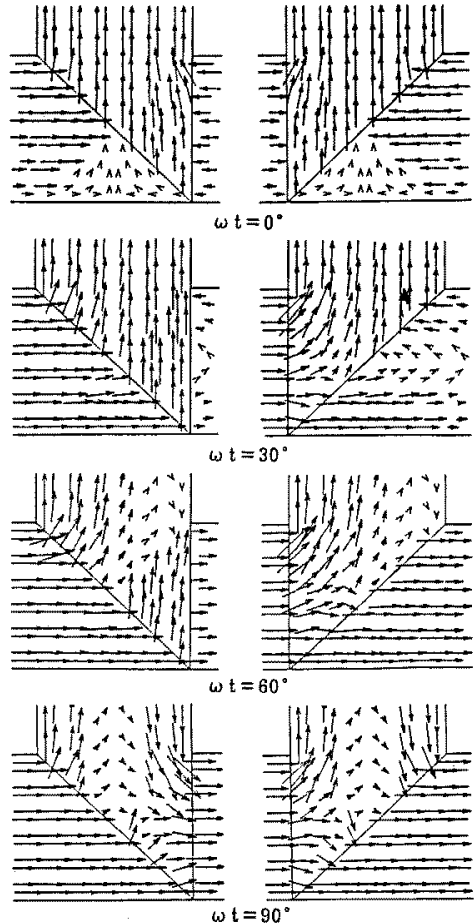

(a) 1 枚圆

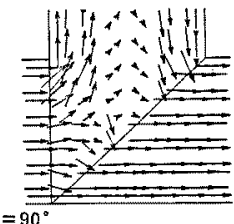

(b) 2 枚目

図 7 各層中の磁束密度べクトル

Fig. 7. Flux density vectors in each layer.

$=0^{\circ}$ とした。

従来法では，区7のような1枚ごとの磁束分布は得 られなかった。鉄損は図 7 の分布によって発生するの で, 従来のように平均の図8で鉄損を推定すると大き な誤差を生じ，鉄心形状や接合法の改良を誤る恐れが ある。

図7からわかるように，混合部における大部分の磁 束は死延方向に通っている。しかし，無方向性ケイ索 鋼板なら磁束のほとんどが $x$ 方向に通る $\omega t=90^{\circ}$ の 瞬間に注，生延方向之直角な力向にもかなりの磁束か 通っている。

因 9 に $T$ 接合部における 1 枚目の鉬板中の，また 図 10 に 1 枚目と 2 枚目の鉬板中の平均の磁束密度べ クトルの時間的な軌跡，すなわち回転磁束密度の空間 的分布を示す。なお，2枚目の鐦板中の分布は，図 9 を寒返したすの上なるので省略した。各図の上方には スケールが描かれている。回転磁束密度の図中の実線 および破線はそれぞれ $\omega t=0^{\circ} ， 90^{\circ}$ における磁束密度 ベクトルを示す。

园 10 の平均的な回転磁束密度の分布を見ると, 混 合部には左右両側に軸比(短軸／長軸)(1の大きい回転
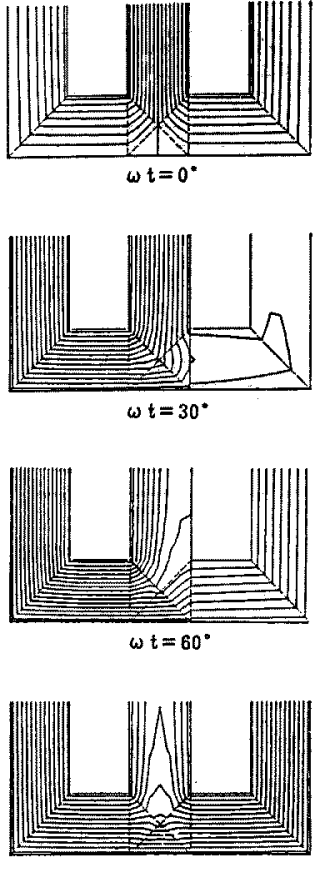

因 8 平均的な磁束分布

Fig. 8. Apparent flux distributions.

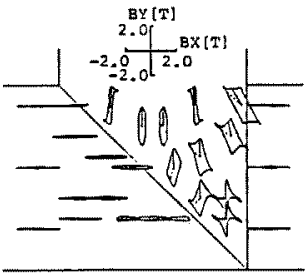

図 91 枚目の䥜板中の回転磁束密度分布

Fig. 9. Loci of the fiux density vectors in the first layer.

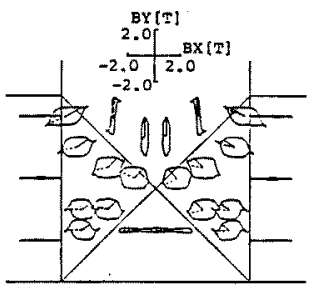

図 10 平均的な回転磁束密度分布

Fig. 10. Loci of the apparent flux density vectors.

磁束が生じているように見えるが，実際には四 9 に示 すように，生延方向が $x$ 方向を向いている左側の部 分では軸比は小さい。しかし，圧延方向が $y$ 方向を 


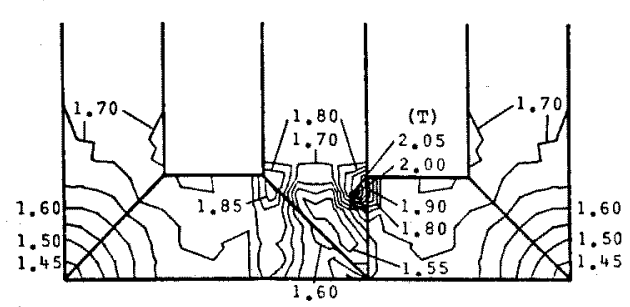

图 11 枚目の最大磁束密度分布

Fig. 11. Distribution of the maximum flux density in the first layer.

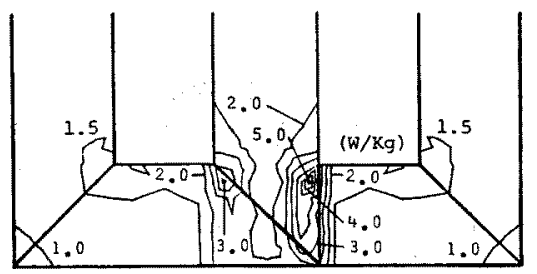

図 $12 \cdot 1$ 枚目の鉄損分布

Fig. 12. Distribution of iron losses in the first layer.

向いている右側の部分では，因 7 の $\omega t=90^{\circ}$ の瞬間を 見てもわかるように， $x$ 方向へ向加う磁束が多くなる ので，回転磁束の軸比は大きなっている。

因 11 亿，1枚目の鉿板中の最大磁束密度の分布を 示す。2枚目の分布は対称なので省略した。図よりわ かるように, 压延方向が $y$ 方向を向いている混合部 の笞近傍が最も磁束密度が高くなっている。てれは、

後述の(3)項で述べるような理由で, 磁束が磁路の短 い空側を通るうとするからである。

（2）鉄嘪分布 因 12 K, 文献（8)で示す方法 で計算した 1 枚目の鋼板中の鉄損分布を示す。2 枚目 の分布は対称なので省略した。因 13 に，1枚目と2 枚目の鉄損を平均した鉄損分布を示す。混合部の㥶近 傍で大きな鉄損が発生しているが，これは，乙の部分 では直角方向にも磁束が通るため，軸比の大きい回転 磁束が発生しているからである。

（3）従来法による解析との比較 本手法で用い るケイ素鋼板の磁化特性としては，図 14 に示すよう な、王延方向およびそれに直角な方向の 2 種類の特性 曲線があれば十分である。それに対し，従来法で湿合 部を含む領域の解析を行う場合には，更に沄合部の平 均的な磁化特性が必要である(9)。

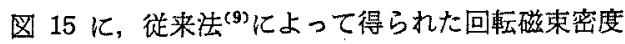
の分布を示す。これは，四 10 の平均的な回転磁束密 度の分布と仪ている。

因 16 に, 従来法によって得られた最大磁束密度

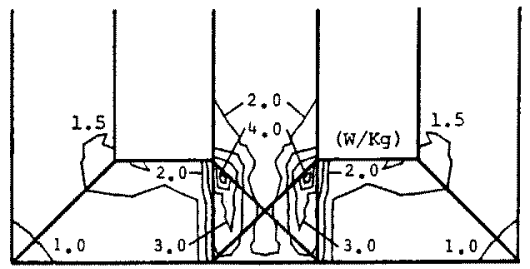

图 13 平均的な鉄損分布

Fig. 13. Distribution of apparent iron losses.

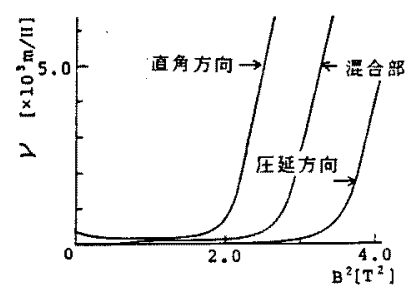

図 14 方向性ケイ素鋝板の $\nu-B^{2}$ 曲線 Fig. 14. $\nu-B^{2}$ curves of grain oriented silicon steel.

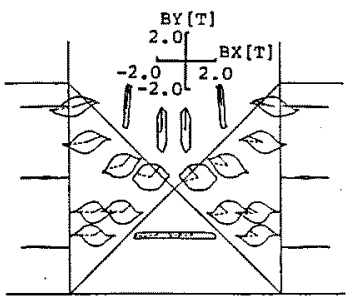

図 15 従来法による回転磁束密度分布 Fig. 15. Loci of the apparent flux density vectors by the conventional method.

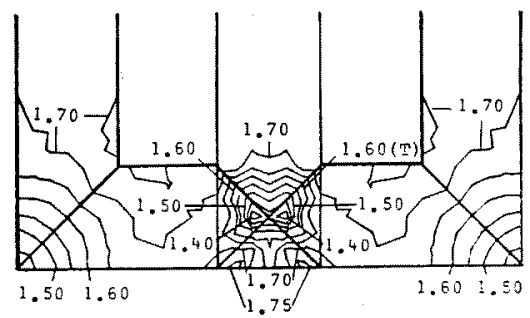

図 16 從来法汪よる最大磁束密度分布

Fig. 16. Distribution of the apparent maximum flux density by the conventional method.

の分布を示す。これは，図 11 に対応するすのである が， $T$ 接合部の分布は大幅に異なっている。すなわ ち、搌合部の空近傍の最大磁束密度が害際よりかなり 低くなっている。図16の分布が，因11 の左方を平 均した分布に近くならない理由は次のとおりである。 例えば，磁束が $W$ 脚から $U$ 脚へ向加う場合，说来 


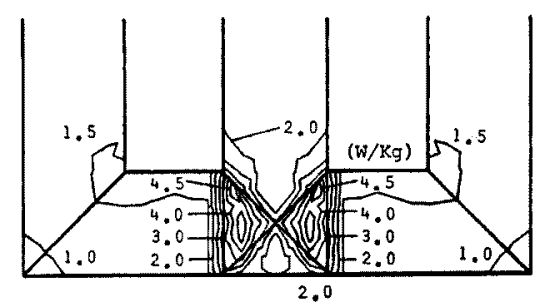

园 17 従来法に上る鉄損分布

Fig. 17. Distribution of apparent iron losses by the conventional method.

法では，混合部の磁化特性曲線上り得られる磁気抵抗 が压延方向のそれよりかなり大きいために，混合部で は飽和しやすく，その結果磁束が均一に分布する。そ れに対し本手法では，混合部でも磁束はなるべく磁気 抵抗の小さい压延方向の鍋板に移行しながら通ってい るので，磁束密度がかなり高い部分がニーナ近傍に発 生し得るのである。

図 17 に従来法によって得られた鉄損分布を示す。 従来法では，次のようにして混合部の鉄提を推定して いた。すなわち，前むって，ある方向书よびそれに直 角な方向に切出した図 3 のような 2 枚の単板試料を重

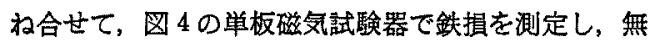
方向性の鋼板として鉄損を推定する。そのために，従 来法による解析では平均的な鉄損しか得られないばか りでなく，鋼板の切出し角の組合甘による鉄提の测定 結果か翼なる問題があったで。それに対し，本手法に よる解析では，鋼板 1 枚ごとの磁束密度が得られるの で問題は生じない。

図 17 之図 13 を比較してわかるように，図 17 の ほうが混合部の鉄損が大きくなっている。てれは，次 のような理由によるあのである。すなわち，混合部で は，新しい解析法によれば，磁束は磁気抵抗が小さい ほうの銅板に渡りながら通っている。これに対し，従 来法では，混合部を厚さ方向の磁束分布が均一な無方 向性の鋼板とみなし，前述したような方法により鉄損 を推定している。このために，说来法による四 17 の ほうが，図13 上りも混合部の鉄損が大きくなる。ま た四 9 の上うに，左右の湿合部のうちの片方では軸比 が非常に小さいにすかかわらず，従来法では图 15 の ように大きな轴比で鉄損計算を行っているためであ る。なお，図 11 のほうか磁束の集中が激しく，図 16 の場合より最大磁束密度は高くなっているが，因16 のほうが高磁束密度になっている領域が図 11 よりあ 広籍囲であるため，鉄損は図16 のほうが多くなって いる。
回転磁束によって生じる鉄挰の推定法は情度的に未 検討な部分が多いので，てれについては現在詳細な寒 験的検討を進めている。

\section{4.むすび}

本手法の開発により，従来の二次元解析では困讙で あった，压延方向の異なったケイ素鋼板が皘屬されて いる鉄心中の，鋼板 1 枚どとの磁束分布の詳細が容易 に解析できるようになった。本手法を用いて得られた 解析結果は，最適な鉄心構造を研究するための有用な 指針となるであろう。

本手法は， $x ， y$ 方向の磁束成分しか考慮していな い近仪三次元解析であるため，ケイ续鋼板の接合部近 傍に生じる鋼板に垂直な方向の磁束成分は無視されて いる。しかし，とれらの磁束は渦電流を発生させ、鉄 損增加の原因となるので，ての垂直磁束も考虑できる 解析手法の開発が必要である。また，材料のヒステリ シス特性を無視しているが，ケイ素鋼板内のミクロな 磁束分布を正確に知るためには，ヒステリシスの考虑 が必要である。従来の二次元解析には既にヒステリシ スが考虑され(10), 変圧器鉄心の解析に応用されてお り，今後ヒステリシスを考虑できるように本手法を改 良する予定である。

(昭和 61 年 9 月 19 日受付)

\section{文献}

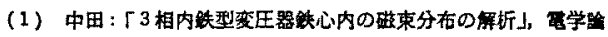
B, 95, 217 (昭 50-5)

(2) T. Nakata, et al.; "Non.Linear Analysis of Rotating Flux in the T-joints of a Three-phase, Three-Limed Transformex", European Physical Society Conf. Proc. of Soft Magnetic Materials, 2, 4-5, 57 (1975)

(3) T. Nakata, et al.: "Numerical Solution of Flux Distributions in Transformer Cores". International Symp. on Electrodynamics Forces and Losses in Transformers, c2, 243 (1979)

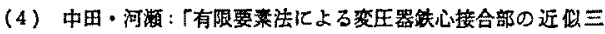

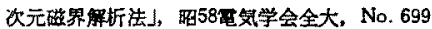

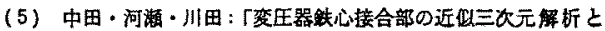

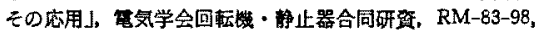
SA-83-43 (1983)

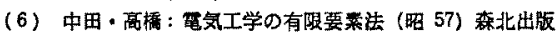

(7) T. Nakata, N. Takahashi, Y. Kawase \& M. Nakano: "Infuence of Lamination Orientation and Stacking on Magnetic Characteristics of Gain-Oriented Silicon Steel Laminations", IEEE Trans. Magnetics, MAG-20, 5, 1774 (1984)

（8）石原・中田・赤穗:「有限要美法による外鉄型三相三湖变印

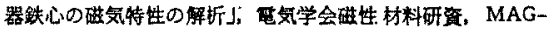
78-1 (掏 53)

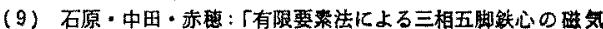
特性の解析与，电気学会磁性材料研资，MAG-78-49 (昭 53)

(10) T. Nakata, N. Takahashi Y. Kawase: "Finite Element Analysis of Magnetic Fields Taking into Account Hysteresis Characteristics", IEEE Trans. Magnetics, MAG $-21,5,1856$ (1985) 